\title{
Correction to: Inhibition of melanin production by anthracenone dimer glycosides isolated from Cassia auriculate seeds
}

\author{
Weicheng Wang ${ }^{1} \cdot$ Yi Zhang $^{1,2} \cdot$ Souichi Nakashima ${ }^{1,3} \cdot$ Seikou Nakamura ${ }^{1} \cdot$ Tao Wang $^{1,2} \cdot$ Masayuki Yoshikawa ${ }^{1}$. \\ Hisashi Matsuda ${ }^{1}[$
}

Published online: 10 April 2020

(c) The Author(s) 2020

\section{Correction to: Journal of Natural Medicines (2019) 73:439-449 https://doi.org/10.1007/s11418-018-01276-2}

The article Inhibition of melanin production by anthracenone dimer glycosides isolated from Cassia auriculata seeds, written by Weicheng Wang, Yi Zhang, Souichi Nakashima, Seikou Nakamura, Tao Wang, Masayuki Yoshikawa and Hisashi Matsuda was originally published Online First without Open Access. After publication in volume 73 issue 3, page 439-449 the author decided to opt for Open Choice and to make the article an Open Access publication. Therefore, the copyright of the article has been changed to (C) The Author(s) 2020 and the article is forthwith distributed under the terms of the Creative Commons Attribution 4.0 International License (https://creativecommons.org/licenses/ by/4.0/), which permits use, duplication, adaptation, distribution and reproduction in any medium or format, as long as you give appropriate credit to the original author(s) and the source, provide a link to the Creative Commons license, and indicate if changes were made.

The original article was updated.

Open Access This article is licensed under a Creative Commons Attribution 4.0 International License, which permits use, sharing, adaptation, distribution and reproduction in any medium or format, as long

The original article can be found online at https://doi.org/10.1007/ s11418-018-01276-2.

Hisashi Matsuda

matsuda@mb.kyoto-phu.ac.jp

1 Kyoto Pharmaceutical University, Misasagi, Yamashina-ku, Kyoto 607-8412, Japan

2 Tianjin State Key Laboratory of Modern Chinese Medicine, Tianjin University of Traditional Chinese Medicine, 312 Anshanxi Road, Nankai District, Tianjin 300193, China

3 N.T.H Co., Ltd., 4F Sky-ebisu Bldg, 1-8-11 Ebisu, Shibuya-ku, Tokyo 150-0013, Japan as you give appropriate credit to the original author(s) and the source, provide a link to the Creative Commons licence, and indicate if changes were made. The images or other third party material in this article are included in the article's Creative Commons licence, unless indicated otherwise in a credit line to the material. If material is not included in the article's Creative Commons licence and your intended use is not permitted by statutory regulation or exceeds the permitted use, you will need to obtain permission directly from the copyright holder. To view a copy of this licence, visit http://creativecommons.org/licenses/by/4.0/.

Publisher's Note Springer Nature remains neutral with regard to jurisdictional claims in published maps and institutional affiliations. 